\title{
THE BIOLOGICAL AFFINITY OF THE ANCIENT POPULATIONS OF ALTAR DE SACRIFICIOS AND SEIBAL
}

\author{
Donald M. Austiv \\ Southern Methodist University
}

\section{INTRODUCTION}

The question of biological affinity between ancient populations is often an intriguing one. Unfortunately, the fragmentary nature and paucity of skeletal remains usually obviate the possibility of using genetically determined cranial and postcranial traits to assess biological affinity. The teeth, due to their more durable nature, present more potential for genetic analysis than the bony remains. Dental traits are ideal morphological characteristics on which to base estimates of genetic distance between populations. Twin and intrafamily studies have demostrated that many morphological characteristics of the dentition are heritable (Kraus, 1951; Kraus and Furr, 1953; Kraus, 1957; Ludwig, 1957; Lundstrom, 1963; Garn, Lewis and Polacheck, 1960; Green and Aszkler, 1970; Tsuji, 1958; Greene, 1967b). Population distribution studies have shown that populations can be differentiated on the basis of varying frequencies of particular dental traits (Hanihara, 1963 and 1967; Dahlberg, 1951; Greene, 1967a and 1967b).

In the lowland Maya area the biological affinity of populations is of interest because of the apparent population migration into this region during the Late Classic Period. Changes in art styles, ceramics and settlement patterns, noticed by R. E. W. Adams (1964) and Sabloff and Willey (1967) among others, have been attributed to this migration.

If different gene pools were involved in this population shift, it may be possible to find genetic evidence (in the form of dental morphological differences) of the migration by comparing early and late populations at Maya sites. 
The objective of this study, then, is to assess the genetic continuity through time of two ancient lowland Maya populations.

\section{METHODS}

\section{Samples}

Dental materials from two Maya sites, Altar de Sacrificios and Seibal, Guatemala, were available for use in this study. The skeletal remains from the sites were collected by personnel of the Peabody Museum of Harvard University during the excavation of the sites in the 1959-63 and 1964-68 field seasons, respectively. These excavations were conducted by G. R. Willey, project Director, and A. L. Smith, Field Director (Willey and Smith, 1969; Smith and Willey, 1969). Permission to examine the burials was granted by Frank P. Saul who has undertaken the laboratory analysis of them (Saul, 1972). The remains of 113 individuals exhibited dentitions that were satisfactory for examination. The chronological distribution of the remains are presented in Table 1. Harvard personnel assigned individuals to cultural phases on the basis of ceramic associations.

The samples are probably not representative (in the statistical sense of the term) of the populations that inhabited the two sites and the immediately surrounding areas. The sample sizes are very small and the recovery of individuals was not random. Only the remains of those individuals buried in archeologically important areas had a chance of being recovered. The two samples are probably quite similar to each other as far as factors related to social class are concerned since the same types of structures and areas were excavated at both sites. Thus, genetic differences between the samples caused by potential interclass genetic heterogeneity and the subsequent inclusion of different segments of the populations into the samples are probably minimal.

\section{Research Design}

In order to find genetic evidence of population migration at Altar de Sacrificios and Seibal, the samples from each site were divided into an early and a late subsample. The small sizes prevented the utilization of more than two chronological groupings. 
TABLE 1

CHRONOLOGICAL DISTRIBUTION OF SAMPLE

\begin{tabular}{|c|c|c|}
\hline Phase & $\begin{array}{c}\text { ALTAR } \\
\text { Chronology }\end{array}$ & $\begin{array}{l}\text { Number of } \\
\text { Individuals }\end{array}$ \\
\hline $\begin{array}{l}\text { Xe } \\
\text { San Felix } \\
\text { Plancha } \\
\text { Salinas } \\
\text { Ayn } \\
\text { Veremos } \\
\text { Chixoy } \\
\text { Pasion } \\
\text { Boca or Jimba } \\
\text { Other (these could } \\
\quad \text { single phase) }\end{array}$ & $\begin{array}{l}800 \text { B.C.-600 B.C. } \\
600 \text { B.C.-250 B.C. } \\
250 \text { B.C.-50 A.D. } \\
50 \text { A.D.-300 A.D. } \\
300 \text { A.D.-550 A.D. } \\
550 \text { A.D.-600 A.D. } \\
600 \text { A.D.-650 A.D. } \\
650 \text { A.D.-750 A.D. } \\
750 \text { A.D.-925 A.D. } \\
\text { be assigned to a }\end{array}$ & $\begin{array}{r}1 \\
4 \\
11 \\
1 \\
3 \\
2 \\
0 \\
4 \\
36\end{array}$ \\
\hline Phase & $\begin{array}{c}\text { SEIBAL } \\
\text { Chronology }\end{array}$ & $\begin{array}{l}\text { Number of } \\
\text { Individuals }\end{array}$ \\
\hline $\begin{array}{l}\text { Real } \\
\text { Escoba } \\
\text { Cantutse } \\
\text { Junco } \\
\text { Unclassified phase } \\
\text { Tepejilote } \\
\text { Bayal } \\
\text { Other (these coulc } \\
\quad \text { single pha }\end{array}$ & $\begin{array}{l}800 \text { B.C. }-600 \text { B.C. } \\
600 \text { B.C.-300 B.C. } \\
300 \text { B.C.-275 A.D. } \\
275 \text { A.D.-500 A.D. } \\
500 \text { A.D.-700 A.D. } \\
700 \text { A.D.-825 A.D. } \\
825 \text { A.D.-925 A.D. } \\
\text { ot be assigned to a }\end{array}$ & $\begin{array}{c}0 \\
2 \\
4 \\
0 \\
\text { no data } \\
9 \\
30 \\
2 \\
2\end{array}$ \\
\hline
\end{tabular}

Note: Smith and Willey (1969: 152). The Boca and Jimba phases at Altar have been combined because of difficulties in accurately placing many of the individuals in one or the other phase.

As Table 2 illustrates, the early period at Seibal includes those individuals assigned to phases dated at between 800 B.C. and 800 A.D. The late period includes individuals assigned to the Bayal Phase, from 800 A.D. to 900 A.D. Individuals included in the early and late periods at Altar come from similar time spans, 800 B.C. to 750 A.D. and 750 A.D. to 900 A.D., respectively. This grouping defines four subsamples, and early and late group from each site. Migration into the area probably occurred at around 800 A.D. (Sabloff and Willey 1967). Thus, the early groups should be composed primarily of individuals native to the sites and 
TABLE 2

CHRONOLOGICAL PERIOD DEFINITIONS

\begin{tabular}{|c|c|c|c|}
\hline PERIOD & $\begin{array}{l}\text { Seibal } \\
\text { Phases }\end{array}$ & TIME SPAN & TIME SPAN \\
\hline EARLY & $\begin{array}{l}\text { Real } \\
\text { Escoba } \\
\text { Cantutse } \\
\text { Junco } \\
\text { Tepejilote }\end{array}$ & $\begin{array}{l}\text { ca. } 800 \text { B.C.- } \\
800 \text { A.D. }\end{array}$ & $\begin{array}{l}\text { Xe ca. } 800 \text { B.C.- } \\
\text { San Felix } 750 \text { A.D. } \\
\text { Plancha } \\
\text { Salinas } \\
\text { Ayn } \\
\text { Veremos } \\
\text { Chixoy } \\
\text { Pasion }\end{array}$ \\
\hline LATE & Bayal & $\begin{array}{l}\text { ca. } 800 \text { A.D. } \\
900 \text { A.D. }\end{array}$ & $\begin{array}{lr}\text { Boca } & \text { ca. } 750 \text { A.D.- } \\
\text { Jimba } & 900 \text { A.D. }\end{array}$ \\
\hline
\end{tabular}

the late groups should represent the immigrants. By comparing the genetic distances between the subsamples it should be possible to learn something about the genetic continuity at these sites. Because the two archeological sites are located about 50 kilometers apart one might expect only small differences between the gene pools of the sites, both before and after any large scale migration. If migration did not occur, the between-site and between-chronological period genetic distances would be expected to be relatively small. If migration into the sites did occur during the late period, however, the genetic distance between the chronological periods at both sites should be large relative to the between-site distance, assuming that different gene pools were involved.

\section{Techniques}

The individual count method was employed in this analysis. This technique involves using individuals as the statistical unit as opposed to teeth. This is accomplished by utilizing only one side of the dentition (the left half in the present investigation) for evaluating dental morphology. Consequently, there is only one observation per individual for a given trait instead of two as when both homologous teeth are examined. Greene (1967b: 127) has pointed out at length the disadvantages of lumping left and right teeth in dental analysis. 
The objectives and methods of this study ideally require three analyses. These consist of concordance analysis, analysis of sexual dimorphism, and finally, genetic distance analysis.

Concordance analysis is simply a determination of the degree of bilateral symmetry of the dental characteristics being analyzed. If a trait exhibits a high degree of concordance then, when a particular tooth is absent its antimere may be substituted for analytical purposes. This is done to enlarge the sample when teeth are examined on an individual count basis. Sexual dimorphism must be considered unless the proportions of males and females in the populations are equal or unless the traits under consideration do not vary with respect to sex. With the completion of these preliminary analyses an appropriate genetic distance function may be applied to the traits to assess genetic continuity across space and time.

Although there are apparently a large number of hereditary traits found in the human dentition (Krogman, 1967) not all of them are suitable for use in this type of analysis. Traits should generally meet these four requirements:

1) the traits should be independent of each other.

2) the traits should not present undue difficulty in measurement or classification.

3) the traits must be present in frequencies great enough to be of use in statistical testing.

4) the traits must be variable enough among populations to be of use in differentiating those populations.

The following traits in the permanent dentition were selected for use in the present study because they appear to fulfill the above requirements:

1) upper mesial incisor shoveling

2) upper first molar cusp number

3) upper second molar cusp number

4) upper third molar cusp number

5) lower first molar cusp number

6) lower second molar cusp number

7) lower third molar cusp number

8) lower first molar cusp pattern

9) lower second molar cusp pattern

10) lower third molar cusp pattern

11) Carabelli trait on the upper first molar

Shoveling of the upper lateral incisors was deleted from consideration because this trait is highly related to shoveling on the 
mesial incisor. Similarly, although the Carabelli trait may be present on any of the upper molars only its presence on the upper first molar was analyzed. The trait is usually expressed to its greatest degree on this molar and if found on the second or third molars it is present on the first molar also.

Three traits often recorded by other investigators were not used in this study because they do not meet the previously stated requirements or the more basic requirement of heritability. Premolar and molar root fusion is sometimes reported in studies of dental morphology but very little is known about the genetic factors involved in this condition (Greene, 1967b: 152). Third molar agenesis is a trait frequently reported but, besides being difficult to diagnose in fragmentary dentitions, it may be quasicontinuous in nature (Gruneberg, 1952). That is, the trait, though present genotypically, may not be penetrant depending on the genetic or developmental environment of the individual (Gruneberg, 1951; Hunt, 1966). The protostylid trait was not considered in this study due to its low frequency in the Altar and Seibal samples.

The crown diameters of the teeth are highly interrelated. This is true for teeth of the same class and for all of the teeth in a particular quadrant (Garn, Lewis, and Kerewsky, 1964; Moorees and Reed, 1964). Therefore, crown diameters should not be analyzed as independent variables and they have not been utilized in this study.

\section{Classification of Morphological Traits}

Dahlberg's dental plaques for the establishment of standards for the classification of tooth characteristics were used as guides in the classification of morphological traits (Dahlberg, 1956).

If a tooth exhibited a trait that clearly could not be placed in any of the established categories either because of excessive wear or anomolous morphology that tooth was classified unknown for the particular trait. Otherwise, the tooth was placed in the category that most accurately described it. Unerupted teeth were included in the sample if the crown was complete and its configuration was well defined.

Incisor Shoveling. The shoveling of the maxillary mesial incisors was classified only as absent or present. This was done primarily to increase the sample size. Incisors could have been classified on 
the basis of the degree of shoveling present but many incisors were too worn to permit this more detailed categorization.

Cusp Number. In the determination of cusp number, a cusp was defined as a major prominence on the occlusal surface set off from other such prominences by marked fissures running to the edge of the occlusal surface. Determination of the upper molar cusp number was aided by observing Dahlberg's plaque P9 and choosing type specimens from the samples. These teeth were then used as references. The cusp numbers were initially classified as 4, 4-, 3+, and 3, as proposed by Dahlberg (1951). Another category, $3-$, for molars that were more reduced than the 3 category was added during the analysis. All molars were examined twice to ensure correct classification. Two notable variations occurred in regard to cusp number. A number of upper molars exhibited a distobuccal cusp that was split by a fissure running buccolingually. This split cusp was considered a single cusp. The other variation was the presence of an additional very reduced cusp, or cuspule, occurring adjacent to the reduced distolingual cusp on several $3+$ molars. Greene has also reported this configuration and termed it a $3++(1967$ a: 15$)$. This type, $3++$, was considered a $3+$ for analytical purposes.

The classification of the lower molar cusp number was not so complicated. In addition to the five and four cusp categories, a category for six cusped molars was necessary. Into this category were placed those teeth that had a supernumerary distolingual cusp or "entoconulid".

Cusp Pattern. The configuration of the lower molar cusps was classified as either a $\mathrm{Y}$ or + pattern. The criterion used in distinguishing the two forms was the presence or absence of an area of contact between the mesiolingual and distobuccal cusps. There was little difficulty in determining into which category a tooth should be placed.

Carabelli Trait. This trait was classified only as present or absent in order to avoid small subclass sample sizes and to enlarge the total sample. Many teeth exhibited the trait but were worn to the extent that the degree of expression of the trait could not be ascertained. Classifying the trait according to the degree of expression of the Carabelli Trait would have reduced the sample size. 


\section{Concordance Analysis}

Individuals were scored concordant for a trait if both teeth of the same class (e.g., left and right lower first molar) exhibited the same variation of a particular trait (e.g., if left and right first molars both exhibited the $\mathrm{Y}$ pattern). The concordance of a trait was calculated by dividing the number of individuals concordant for that trait by the total number examined for the trait and expressing the result as a percentage.

\section{Sexual Dimorphism}

The number of individuals of known sex, particularly females, in the two samples is relatively small and, because many of the individuals lack a number of teeth, functional sample size is even smaller. Therefore, no analysis of sexual dimorphism was carried out. It has been demonstrated by other investigators, however, that sexual dimorphism is probably not an important consideration when analyzing the discontinuous variables used in this study (Greene, 1967b; Garn, Lewis, and Kerewsky, 1966: 1823; Meredith and Hixon, 1954; Oliveira, 1961; Tsuji, 1958; Jorgensen, 1955; Greene, 1967a). On the basis of this evidence, the traits were analyzed without regard to sex.

\section{Genetic Distance Analysis}

Genetic distance was determined through the use of the $\mathrm{Dk}^{2}$ distance coefficient for qualitative variables introduced by Kurczynski (1970). The coefficient was calculated by the non-matrix method presented by Constandse-Westermann (1972). This coefficient allows the use of unequal subsamble sizes, an important consideration in the analysis of skeletal remains.

The distance coefficient between two populations is calculated by computing mean weighted frequencies for all attributes in a trait class. The sample differences for each attribute are squared, divided by the weighted frequencies and then summed to arrive at the distance coefficient. Four genetic distances were calculated. These assess the affinity between 1) early Altar and early Seibal, 2) late Altar and late Seibal, 3) early and late Altar, and 4) early and late Seibal. 
One trait was deleted from the study because it was not present in one of the subsamples. No upper third molars were found in the early Seibal group. Therefore, upper third molar cusp number was omitted from the analysis. This brought the number of traits used for genetic distance analysis to ten.

\section{RESULTS}

Concordance Analysis

The results of the analysis for concordance, or bilateral symmetry, are summarized in Table 3. The high degrees of concordance appear to justify using one tooth of any homologous pair as a means of representing the genotype of the individual. This, in effect, enlarges the sample since left and right teeth from different individuals may be compared. Of the traits considered, only the upper third molar cusp number exhibits a relatively low degree of bilateral symmetry. This may be due to sampling error

TABLE 3

CONCORDANCE IN DENTAL TRAITS OF INDIVIDUALS FROM ALTAR AND SEIBAL

\begin{tabular}{lcc}
\hline \hline \multicolumn{1}{c}{ Trait } & $\begin{array}{c}\text { Number of } \\
\text { Individuals }\end{array}$ & $\begin{array}{c}\text { Percent } \\
\text { Concordance }\end{array}$ \\
\hline $\begin{array}{c}\text { Shovel Shaping of Mesial } \\
\text { Incisor }\end{array}$ & 21 & 100.0 \\
Carabelli trait: & & \\
upper first molar & 48 & 85.4 \\
Cusp number: & & \\
lower first molar & 48 & 100.0 \\
lower second molar & 37 & 94.6 \\
lower third molar & 23 & 91.3 \\
upper first molar & 49 & 93.9 \\
upper second molar & 38 & 94.7 \\
upper third molar & 20 & 75.0 \\
Cusp pattern: & & 89.4 \\
lower first molar & 47 & 97.5 \\
lower second molar & 40 & 100.0 \\
lower third molar & 23 & \\
\hline
\end{tabular}


but, as explained previously, this trait was not included in the genetic distance analysis since no upper third molars were present in one of the subsamples.

\section{Genetic Distance Analysis}

The trait attributes used, subsample sizes and attribute frequencies are presented in Tables 4 and 5. Traits 1 and 2, the shovel and Carabelli traits, are classified as either present or absent. Traits 3 through 8, lower and upper molar cusp numbers, are listed according to the number of attributes present. For example, only two types of upper first molar cusp configurations were present in the sample, the 4 and $4-$ types. Four cusp configurations were found in the upper second and third molars, however. Traits 9, 10 and 11, lower molar cusp patterns, are classified as + or Y. As Table 4 illustrates, the early Seibal subsample is much smaller than the other subsamples, late Seibal and early Altar are similar in size, and late Altar is the largest subsample for most of the traits.

The distance coefficients $\left(\mathrm{Dk}^{2}\right)$ calculated from these data are presented in Table 6. Examination of the two between-site coefficients shows that the later subsamples are slightly more similar than the earlier ones since the $\mathrm{Dk}^{2}$ values are 2.71 and 3.57 , respectively. These values can be used as a baseline, in accord with the research design, when examining the chronological distance coeficients. The early and late subsamples from Altar are very similar. The distance coefficient for these subsamples is 0.96 , smaller than either between-site value (see figure 1). This suggests genetic continuity through time at Altar. However, at Seibal the

\section{LATE}

ALTAR

2.71

LATE

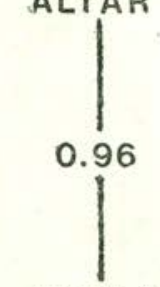

EARLY

ALTAR

3.57

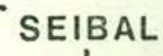

Figure 1. Genetic distance coefficients between Altar and Seibal subsamples. 
TABLE 4

DENTAL TRAITS, SUBSAMPLE SIZES AND

TRAIT FREQUENCIES OF THE SEIBAL SUBSAMPLES

\begin{tabular}{|c|c|c|c|c|c|}
\hline Trait & Attribute & & arly & & $\begin{array}{l}\text { tte } \\
\text { bal }\end{array}$ \\
\hline 1. Shovel Trait & $\begin{array}{l}\text { present } \\
\text { absent }\end{array}$ & $\begin{array}{l}n \\
5\end{array}$ & $\begin{array}{l}\% \\
.800 \\
.200\end{array}$ & $\stackrel{n}{11}$ & $\begin{array}{l}\% \\
.910 \\
.090\end{array}$ \\
\hline 2. Carabelli Trait & $\begin{array}{l}\text { present } \\
\text { absent }\end{array}$ & 8 & $\begin{array}{l}.818 \\
.182\end{array}$ & 22 & $\begin{array}{l}.875 \\
.125\end{array}$ \\
\hline $\begin{array}{l}\text { 3. First } \\
\text { Lower Molar } \\
\text { Cusp Number }\end{array}$ & $\begin{array}{l}4 \\
5 \\
6\end{array}$ & 9 & $\begin{array}{l}.000 \\
.888 \\
.112\end{array}$ & 18 & $\begin{array}{l}.000 \\
.389 \\
.611\end{array}$ \\
\hline $\begin{array}{l}\text { 4. Second } \\
\text { Lower Molar } \\
\text { Cusp Number }\end{array}$ & $\begin{array}{l}4 \\
5 \\
6\end{array}$ & 4 & $\begin{array}{l}.500 \\
.500 \\
.000\end{array}$ & 16 & $\begin{array}{l}.250 \\
.250 \\
.500\end{array}$ \\
\hline $\begin{array}{l}\text { 5. Third } \\
\text { Lower Molar } \\
\text { Cusp Number }\end{array}$ & $\begin{array}{l}4 \\
5 \\
6\end{array}$ & 3 & $\begin{array}{l}.667 \\
.000 \\
.333\end{array}$ & 12 & $\begin{array}{l}.083 \\
.167 \\
.750\end{array}$ \\
\hline $\begin{array}{l}\text { 6. First Upper Molar } \\
\text { Cusp Number }\end{array}$ & $\begin{array}{l}4- \\
4\end{array}$ & 7 & $\begin{array}{l}.286 \\
.714\end{array}$ & 22 & $\begin{array}{l}.455 \\
.545\end{array}$ \\
\hline $\begin{array}{l}\text { 7. Second Upper Molar } \\
\text { Cusp } \\
\text { Number }\end{array}$ & $\begin{array}{l}3 \\
3+ \\
4- \\
4\end{array}$ & 8 & $\begin{array}{l}.125 \\
.000 \\
.500 \\
.375\end{array}$ & 19 & $\begin{array}{l}.158 \\
.104 \\
.684 \\
.052\end{array}$ \\
\hline $\begin{array}{l}\text { 8. Third Upper Molar } \\
\text { Cusp } \\
\text { Number* }\end{array}$ & $\begin{array}{l}3- \\
3 \\
3+ \\
4-\end{array}$ & & & 16 & $\begin{array}{l}.187 \\
.313 \\
.500 \\
.000\end{array}$ \\
\hline $\begin{array}{l}\text { 9. First Lower Molar } \\
\text { Cusp Pattern }\end{array}$ & $\stackrel{+}{\mathrm{Y}}$ & 8 & $\begin{array}{l}.250 \\
.750\end{array}$ & 20 & $\begin{array}{l}.250 \\
.750\end{array}$ \\
\hline $\begin{array}{l}\text { 10. Second Lower Molar } \\
\text { Cusp Pattern }\end{array}$ & $\stackrel{+}{\mathrm{Y}}$ & 8 & $\begin{array}{l}.875 \\
.125\end{array}$ & 19 & $\begin{array}{l}1.00 \\
0.00\end{array}$ \\
\hline $\begin{array}{l}\text { 11. Third Lower Molar } \\
\text { Cusp Pattern }\end{array}$ & $\stackrel{+}{\mathrm{Y}}$ & 3 & $\begin{array}{l}1.00 \\
0.00\end{array}$ & 13 & $\begin{array}{l}.846 \\
.154\end{array}$ \\
\hline
\end{tabular}

* This trait was not used in the calculation of the genetic distance coefficient. 
TABLE 5

DENTAL TRAITS, SUBSAMPLE SIZES AND

TRAIT FREQUENCIES OF THE ALTAR SUBSAMPLES

\begin{tabular}{|c|c|c|c|c|c|}
\hline Trait & Attribute & & $\begin{array}{l}\text { Early } \\
\text { Altar }\end{array}$ & & $\begin{array}{l}\text { ate } \\
\text { lltar }\end{array}$ \\
\hline 1. Shovel Trait & $\begin{array}{l}\text { present } \\
\text { absent }\end{array}$ & $\begin{array}{r}n \\
15\end{array}$ & $\begin{array}{l}\% \\
1.00 \\
0.00\end{array}$ & $\begin{array}{l}n \\
9\end{array}$ & $\begin{array}{l}\% \\
1.00 \\
0.00\end{array}$ \\
\hline 2. Carabelli Trait & $\begin{array}{c}\text { present } \\
\text { absent }\end{array}$ & 18 & $\begin{array}{l}.722 \\
.278\end{array}$ & 27 & $\begin{array}{l}.815 \\
.185\end{array}$ \\
\hline $\begin{array}{l}\text { 3. First } \\
\text { Lower Molar } \\
\text { Cusp Number }\end{array}$ & $\begin{array}{l}4 \\
5 \\
6\end{array}$ & 19 & $\begin{array}{l}.000 \\
.632 \\
.368\end{array}$ & 32 & $\begin{array}{l}.063 \\
.625 \\
.312\end{array}$ \\
\hline $\begin{array}{l}\text { 4. Second } \\
\text { Lower Molar } \\
\text { Cusp Number }\end{array}$ & $\begin{array}{l}4 \\
5 \\
6\end{array}$ & 20 & $\begin{array}{l}.550 \\
.300 \\
.150\end{array}$ & 20 & $\begin{array}{l}.400 \\
.400 \\
.200\end{array}$ \\
\hline $\begin{array}{l}\text { 5. Third } \\
\text { Lower Molar } \\
\text { Cusp Number }\end{array}$ & $\begin{array}{l}4 \\
5 \\
6\end{array}$ & 13 & $\begin{array}{l}.692 \\
.154 \\
.154\end{array}$ & 14 & $\begin{array}{l}.428 \\
.286 \\
.286\end{array}$ \\
\hline $\begin{array}{l}\text { 6. First Upper Molar } \\
\text { Cusp Number }\end{array}$ & $\begin{array}{l}4- \\
4\end{array}$ & 17 & $\begin{array}{l}.353 \\
.647\end{array}$ & 26 & $\begin{array}{l}.308 \\
.692\end{array}$ \\
\hline $\begin{array}{l}\text { 7. Second Upper Molar } \\
\text { Cusp } \\
\text { Number }\end{array}$ & $\begin{array}{l}3 \\
3+ \\
4- \\
4\end{array}$ & 20 & $\begin{array}{l}.100 \\
.100 \\
.800 \\
.000\end{array}$ & 30 & $\begin{array}{l}.167 \\
.100 \\
.566 \\
.167\end{array}$ \\
\hline $\begin{array}{l}\text { 8. Third Upper Molar } \\
\text { Cusp } \\
\text { Number* }\end{array}$ & $\begin{array}{l}3- \\
3 \\
3+ \\
4-\end{array}$ & 12 & $\begin{array}{l}.333 \\
.500 \\
.000 \\
.167\end{array}$ & 16 & $\begin{array}{l}.250 \\
.375 \\
.313 \\
.062\end{array}$ \\
\hline $\begin{array}{l}\text { 9. First Lower Molar } \\
\text { Cusp Pattern }\end{array}$ & $\stackrel{+}{\mathrm{Y}}$ & 19 & $\begin{array}{l}.263 \\
.737\end{array}$ & 28 & $\begin{array}{l}.286 \\
.714\end{array}$ \\
\hline $\begin{array}{l}\text { 10. Second Lower Molar } \\
\text { Cusp Pattern }\end{array}$ & $\stackrel{+}{\mathrm{Y}}$ & 20 & $\begin{array}{l}.950 \\
.050\end{array}$ & 23 & $\begin{array}{l}.913 \\
.087\end{array}$ \\
\hline $\begin{array}{l}\text { 11. Third Lower Molar } \\
\text { Cusp Pattern }\end{array}$ & $\stackrel{+}{\mathrm{Y}}$ & 13 & $\begin{array}{l}1.00 \\
0.00\end{array}$ & 16 & $\begin{array}{l}1.00 \\
0.00\end{array}$ \\
\hline
\end{tabular}


TABLE 6 GENETIC DISTANCE COEFFICIENTS $\left(\mathrm{Dk}^{2}\right)$
BETWEEN SUBSAMPLES

\begin{tabular}{|c|c|c|}
\hline & Subsamples & $D k^{2}$ \\
\hline Early & Altar-Early Seibal & 3.57 \\
\hline Late & Altar-Late Seibal & 2.71 \\
\hline Early & Altar-Late Altar & 0.96 \\
\hline Early $s$ & Seibal-Late Seibal & 6.05 \\
\hline
\end{tabular}

results are quite different. The distance coefficient for the early and late subsamples is 6.05 . One would expect a value of this magnitude had there been immigration at Seibal as proposed by Adams (1964) and Sabloff and Willey (1967).

\section{DISCUSSION}

It is obvious that there are limitations to studies of this type. First, in assessing genetic continuity through time only two chronological periods are defined. The early period represents a span of over 1,500 years, a situation imposed by the paucity of skeletal materials recovered from the sites. Second, it is impossible to know how representative the subsamples are of the populations from which they come. Third, the early Seibal subsample is very small and most of the individuals have been placed in a chronological phase, the Tepejilote, that is about 600 yarse later than the phases that include a majority of the early Altarians. This last point may not be too important since, if migration were not a factor, one would then expect the genetic distance between early and late Seibal subsamples to be smaller than the distance between early and late Altar subsamples because of the smaller time increment involved. What we observe is just the opposite. Fourth, genetic distance methods are sometimes difficult to interpret. For example, the coefficients reported here differ from those presented earlier, although they are based upon the same data (Saul and Austin, 1970; Austin, 1971). In the previous papers the author relied upon a distance coefficient that required all traits to be classified as either present or absent. When three or four atributes are present this technique results in a loss of information for 
differentiating populations. For this reason the $\mathrm{Dk}^{2}$ statistic has been utilized. The coefficients reported earlier suggested little genetic change through time at both Altar and Seibal (relative to the intersite differences). It is interesting, as well as encouraging, that the coefficient for early and late Seibal was larger than that for early and late Altar. And, the coefficient for early Altar and early Seibal was larger than that for late Altar and late Seibal. Both of these patterns are found using the $\mathrm{Dk}^{2}$ coefficients.

The small distance coefficient between the early and late Altar subsamples strongly suggests genetic continuity between the populations represented by the burials. At Seibal the distance between the subsamples suggests much less genetic continuity. It appears difficult to explain this difference between the Altar and Seibal subsamples if the proposed migration were of a large scale. Why would there be replacement of social and political upperclass lineages (assuming that is what the majority of the burials represent) at Seibal and not at Altar de Sacrificios? Perhaps this question can be at least partially answered by Marcus' concept of Mayan territorial organization. There may be a relationship between the apparent genetic discontinuity at Seibal and the rise in status of the site to that of "regional capital" by 849 A.D. (Marcus, 1973). We might suppose that the migrants were responsible for this change. If Altar was what Marcus terms a secondary center and was traditionally politically dominated by Seibal, then it may not have been necessary for the migrants to replace the ruling families at Altar in order to gain dominion over it. If this were the case, it is not strange that changes in art styles, ceramics and settlement pattern have been found without evidence of significant genetic change. Ethnographic evidence from modern colonization supports this pattern of cultural change. Assuming that the subsamples are representative of the subpopulations at the sites, this seems to be the simplest argument resolving the suggested differences in genetic continuity at Seibal and Altar de Sacrificios.

\section{BIBLIOGRAPHY}

Adams, Richard E. W.

1964 "The Ceramic Sequence at Altar de Sacrificios and its Implications." Actas del XXXV Congreso Internacional de Americanistas, México, D. F. 1: 371-378. 
Austin, D. M.

1971 "Dental microevolution in two ancient Mayan populations." American Jounral of Physical Anthropology, Vol. 37, No. 3, (abstract).

Constandse-Westermann, T. S.

1972 Coefficients of Biological Distance. Anthropological Pubs. Oosterhout, Netherlands.

DAHLbERG, Albert A.

1951 "The Dentition of the American Indian." Papers on the Physical Anthropology of the American Indian. New York, Viking Fund, Inc., 138-176.

1956 Material for the Establishment of Standards for Classification of Tooth Characters, Attributes, and Techniques in Morphological Studies of the Dentition. Zoller Laboratory of Dental Anthropology, University of Chicago.

Garn, S. M., A. B. Lewis, and R. S. Kerewsky

1964 "Fields of toothsize (mimeo)." Fels Research Institute, Yellow Springs, Ohio.

Garn, S. M., A. B. Lewis, and R. S. KerewsKy

1966 "Extent of Sex Influence on Carabelli's Polymorphism." Journal of Dental Research, Vol. 45: 1823.

Garn. S. M., A. B. Lewis and D. L. Polacheck

1960 "Sibling Similarities in Dental Development." Journal of Dental Research, Vol. 39: 170-175.

Green, L. J. and S. E. Aszkrer

1970 "Intra-Alveolar Dental Development in Twins." Journal of Dental Research, Vol. 49: 631-634.

Greene, D. L.

1967a Dentition of Meroitic, X-Group and Christian Populations from Wadi Malfa, Sudan. Anthropological Papers. Salt Lake City, University of Utah Press.

$1967 b$ "Genetics, Dentition and Taxonomy." University of Wyoming Publications, Vol. 33, Nos. 1, 2, and 3: 93. 168.

Gruneberg, $\mathrm{H}$.

1951 "The Genetics of a Tooth Defect in the Mouse. IV. Quasi-continuous Variations." Journal of Genetics, Vol. 51: $95-411$.

Hanihara, Kazuro

1963 "Crown Characters of the Deciduous Dentition of the Japanese-American Hybrids." In Brothwell, D. R. (ed.), Dental Anthropology. London, Pergamon Press Ltd., 105-124.

1967 "Racial Characteristics in Teeth." Journal of Dental Research, Vol. 46: 923-926.

Hunt, Edward E., Jr.

1966 "The Developmental Genetics of Man," in Falkner, Frank (ed.), Human Development. Philadelphia, W. B. Saunders Co., 76-122. 
JoRgensen, K. D.

1955 "The Dryopithecus Pattern in Recent Danes and Dutchmen." Journal of Dental Research, Vol. 34: 195-208.

Kraus, B. S.

1951 "Carabelli's Anomaly of the Maxillary Molar Teeth." American Journal of Human Genetics, Vol. 3: 348-355.

1957 "The Genetics of the Human Dentition." Journal of Forensic Sciences, Vol. 2: 420-428.

Kraus, B. S. and M. L. FurR

1953 "Lower First Premolars: Part 1." Journal of Dental Research, Vol. 32: 554-564.

KRogman, W. M.

1967 "The Role of Genetic Factors in the Human Face, Jaws, and Teeth: A Review." Eugenics Review, Vol. 59: 165-192.

KURCZYNSKI, T. W.

1970 "Generalized Distance and Discrete Variables." Biome. trics, Vol. 26: 525-535.

Ludwig, F. J.

1957 "The Mandibular Second Premolars: Morphological Variation and Inheritance." Journal of Dental Research, Vol. 36: $263-273$

LUNDSTORM, A.

1963 "Tooth Morphology as a Basis for Distinguishing Mono. zygotic and Dizygotic Twins." American Journal of $\mathrm{Hu}$ man Genetics, Vol. 15: 34-43.

Marcus, J. P.

1973 "Territorial Organization of the Lowland Classic Maya." Science, Vol. 180: 911-916.

Meredith, Howard V. and Earnest H. Hixon

1954 "Frequency, Size, and Bilateralism of Carabelli's Tubercle." Journal of Dental Research, Vol. 33: 435-440.

Moorees, C. F. A. and R. B. Reed

1964 "Correlations among Crown Diameters of Human Teeth." Archives of Oral Biology, Vol. 9: 685-697.

Oliveika, Osmir Luiz

1961 Do Tuberculo De Carabelli. Doctoral Dissertation, Universidade de Manas Gerais, Brazil.

SABLOFF, J. A. and G. R. Willey

1967 "The Collapse of Maya Civilization in the Southern Lowlands: A Consideration of History and Process." Southwestern Journal of Anthropology, Vol. 23, No. 4: 311-336.

SAUL, F. P. and D. M. Austin

1970 "Dental Characteristics of the Ancient Lowland Maya." Bulletin of the American Anthropological Association, Vol. 3, p. 100. 
SAUL, F. P. 1972

"The Human Skeletal Remains of Altar de Sacrificios." Papers of the Peabody Museum of Archaeology and Ethnology, Vol. 63, No. 2, Peabody Museum, Cambridge.

Smith, A. L. and G. R. Willey

1969 "Seibal, Guatemala: A Brief Summary of Archaeological Results." Verhandlungen des XXXVIII Internationlen Amerikanistenkongress, Stuttgart-Munchen 151-158.

TsujI, T.

1958 "Incidence and Inheritance of the Carabelli's Cusp in a Japanese Population." Japanese Journal of Human Genetics, Vol. 3: 21-31 (English Summary).

Willey, G. R. and A. L. Smith

1969 "The Ruins of Altar de Sacrificios, Department of Peten, Guatemala: An Introduction." Papers of the Peabody Museum, Harvard University, Vol. 62, No. 1. 